\title{
STEPPING UP TO THE PODIUM WITH CONFIDENCE: A PRIMER FOR LAW STUDENTS ON PREPARING AND DELIVERING AN APPELLATE ORAL ARGUMENT
}

\author{
James D. Dimitri*
}

\section{INTRODUCTION}

Virtually all law students are required to learn oral advocacy skills at some point during their legal education. Typically, these skills are cultivated through at least one oral argument assignment, which often consists of an appellate oral argument that is given as part of the students' first-year legal research and writing course or as part of a moot court competition.

While appellate courts do not grant oral arguments as often as they used to, ${ }^{1}$ oral advocacy remains a critical skill for law students to learn and cultivate, no matter which area of law they practice upon graduation. ${ }^{2}$ Unfortunately, the prospect of learning this critical skill through an oral argument assignment can be disquieting to students. The main reason for this unease is sim-

* C 2008, James D. Dimitri. All rights reserved. Clinical Associate Professor of Law, Indiana University School of Law-Indianapolis. J.D., summa cum laude, Valparaiso University School of Law, 1993. Professor Dimitri is faculty advisor to his school's Moot Court Society and has coached several award-winning teams in interscholastic moot court competitions. Before his appointment to the IU-Indianapolis faculty, Professor Dimitri served as a deputy attorney general in the Appeals Division of the Indiana Attorney General's Office, where he briefed and argued federal and state appeals. Professor Dimitri thanks his colleagues Ken Chestek, Allison Martin, and Joan Ruhtenberg for their invaluable comments and suggestions on how to improve this Article. He also thanks his research assistant, Cory Lightner, for her input on how to make the Article accessible and helpful to law students.

1. Joseph W. Hatchett \& Robert J. Telfer III, The Importance of Appellate Oral Argument, 33 Stetson L. Rev. 139, 139 (2003). In some jurisdictions, oral arguments are not heard unless a party requests an argument or the court orders an argument. Id.

2. Jennifer Kruse Hanrahan, Truth in Action: Revitalizing Classical Rhetoric as a Tool for Teaching Oral Advocacy in American Law Schools, 2003 BYU Educ. \& L.J. 299, 302 (2003) (quoting Fredrick Bernays Weiner, Oral Advocacy, 62 Harv. L. Rev. 56, 56-58 (1948)). 
ple-most law students have little to no oral advocacy experience. However, students may ease their anxiety and ultimately deliver an excellent oral argument if they fully understand the purposes of the argument and if they thoroughly prepare for the argument.

This Article is targeted at oral argument novices. It discusses how you, as a beginner to appellate oral argument, may effectively prepare and deliver an argument, particularly if you are giving this argument as part of your law school's legal research and writing course or as a competitor in a moot court competition. ${ }^{3}$

\section{THE GENERAL FORMAT OF AN ORAL ARGUMENT}

The typical format of an appellate oral argument is as follows: each party is allotted a set number of minutes to argue its side of the case. ${ }^{4}$ Normally, this time period spans from fifteen to thirty minutes per advocate. ${ }^{5}$ The party appealing the lower court's ruling, usually called the appellant or the petitioner, proceeds first with an opening argument. ${ }^{6}$ The appellant/petitioner is also given the opportunity to reserve a few minutes of his or her total time for a rebuttal argument. ${ }^{7}$ The appellant/petitioner may choose not to reserve rebuttal time if he or she wishes. ${ }^{8}$

After the appellant/petitioner's opening argument, the party who is not appealing the lower court's ruling, usually called the appellee or the respondent, delivers his or her argument. ${ }^{9}$ After the appellee/respondent's argument concludes, the appel-

3. While advice in this Article is geared toward oral arguments given in the appellate context, most of the suggestions made in the Article are also applicable to oral arguments given to a trial court.

4. Bd. of Student Advisers Harv. L. Sch., Introduction to Advocacy: Research, Writing, and Argument, 69 (7th ed., The Found. Press 2002) [hereinafter Introduction to Advocacy]. In its early years, the United States Supreme Court's oral arguments sometimes lasted for days. Id. However, heavy caseloads forced courts to restrict the length of contemporary oral arguments. Id.

5. Ruth Bader Ginsburg, Remarks on Appellate Advocacy, 50 S.C. L. Rev. 567, 567 (1999) (indicating that while the maximum time for an oral argument is thirty minutes, some may be as short as five minutes).

6. Introduction to Advocacy, supra n. 4, at 69.

7. See id. at 79 (stating that rebuttal should be used to clarify previous arguments and respond to the appellee's argument).

8. Id.

9. Id. at 69 
lant/petitioner delivers his or her rebuttal argument. ${ }^{10}$ After the rebuttal, the oral argument is over. ${ }^{11}$

\section{PREPARING AN ORAL ARGUMENT12}

Although delivery of the oral argument should be of great concern to a student advocate, it is absolutely critical that the advocate focus first on preparing for the argument. It simply is not possible to give a good appellate oral argument by "winging" it. Since the key to oral argument is meticulous preparation, I recommend that you take the following steps to prepare for your argument:

(1) Understand the two main purposes of appellate oral arguments-persuasion and education.

(2) With those purposes in mind, conduct a brainstorming session where you think of (a) a theme for your client's case, (b) the important points you need to convey to the court, and (c) the questions that the judges may ask you.

(3) Prepare a short outline to remind you of the points you must convey to the court and to provide you with a "safety net" regarding key facts and legal authority.

(4) Practice and refine your argument.

\section{A. The Purposes behind Oral Argument- Persuasion and Education}

As a student advocate, you should first understand the main purposes of oral argument-persuasion and education. ${ }^{13}$ You need

10. Id.

11. See id. (outlining the structure of an appellate oral argument).

12. In moot court competitions, the advocates are customarily required to argue both sides of the case. In this Article, I do not explicitly discuss how to prepare to argue both sides of the case. Nonetheless, as I discuss below, any good appellate advocate will not only focus on the strengths of her case, but also its weaknesses. An advocate who is familiar with the weaknesses of the side of the case that she briefed will be familiar with the strengths of the side of the case that she did not brief. Hence, the advocate will be able to focus on those strengths to prepare an oral argument for the other side of the case.

13. Alfonso M. Saldana, Beyond the Appellate Brief: A Guide to Preparing and Deliver- 
this understanding because student arguments possess the same dynamics as real appellate court arguments. Therefore, if you understand the two primary purposes behind real appellate oral arguments, you will be better prepared to handle a law school oral argument.

The first purpose of oral argument-persuasion-is related to your role as an advocate before the court. ${ }^{14}$ This role requires you to attempt to convince the court that your client should win the appeal. ${ }^{15}$ You should attempt to do this when you write the brief, and you should attempt to do this again during your oral argument. To persuade the judges that your client has the winning side of the case, your objective should be to convey to the court the theme of your client's case and the key points of your client's argument. ${ }^{16}$

The second purpose of oral argument-education-is a function of the court's role in the appellate process. ${ }^{17}$ Appellate courts do not set every case for oral argument. ${ }^{18}$ Often, appellate courts decide cases without oral argument, on the briefs the parties submit to the court. ${ }^{19}$ Thus, in those cases where the court does hear oral argument, the court must have an important reason for calling the lawyers before it to argue the case. ${ }^{20}$ In most cases, the main reason the court sets oral argument is to ask questions about the case. ${ }^{21}$ Unfortunately, some unseasoned advocates are

ing the Oral Argument, 69 Fla. B.J. 28, 28 (May 1995).

14. Id.

15. See id. (stating that the purpose of an oral argument is "to persuade a judge to change his or her mind, and to convince an undecided judge").

16. See Introduction to Advocacy, supra n. 4, at 71 (highlighting the importance of developing a core theory for your argument).

17. See Saldana, supra n. 13, at 28 (stating that the purpose of the oral argument is to enhance the court's understanding of the issues presented in your brief).

18. See accord Hatchett \& Telfer, supra n. 1, at 140 (stating that oral arguments have become less common).

19. See id. (indicating that oral argument has become less common because courts generally grant them only for cases with "important" or complex issues).

20. Id.

21. Jacques L. Wiener, Jr., Ruminations from the Bench: Brief Writing and Oral Argument in the Fifth Circuit, 70 Tul. L. Rev. 187, 199-200 (1995); see Henry D. Gabriel, Preparation and Delivery of Oral Argument in Appellate Courts, 22 Am. J. Tr. Advoc. 571, 573 (1999) (stating that one of two uses for oral argument is to allow counsel to respond to the court's concerns). Admittedly, some courts may schedule oral arguments to learn basic information about a case because they have had little time to read the parties' briefs and the record of the proceedings from the court below. Today, however, appellate judges are rarely unfamiliar with the cases pending before them. See e.g. Wiener, supra n. 21, at 199 
under the mistaken impression that they are called before the court to give an uninterrupted speech. ${ }^{22}$ However, an oral argument is not a monologue where the advocate simply gives a rhetorical account of his or her side of the case; rather, it is a dialogue between the bench and the advocate, where the advocate serves as an advisor to the court and educates the judges about the case. ${ }^{23}$

In this educational dialogue, appellate courts ask the advocates questions for several different reasons. First, and most commonly, the judges want to identify the most important issue or issues in a case. ${ }^{24}$ This may be necessary if the parties have presented multiple issues in their briefs, some of which are fairly simple and can easily be disposed of by the court, while others are intricate and require further and more involved discussion. ${ }^{25} \mathrm{In}$ other words, the court may desire a dialogue with the lawyers to separate the wheat from the chaff.

Second, the parties' briefs may only peripherally touch on issues the court deems central to a case and about which the court wants to learn. ${ }^{26} \mathrm{Or}$, similarly, the briefs may not thoroughly discuss very complex issues about which the court needs more information. ${ }^{27}$ Therefore, the court may want the advocates to clar-

(stating that the Fifth Circuit generally tells advocates at the beginning of arguments that the court has read the briefs and relevant portions of the record). Similarly, arguments with "cold" benches, where the judges ask few questions of the advocates, are not commonplace. See e.g. id. (stating that the Fifth Circuit identifies itself at the beginning of arguments as a "hot" bench).

22. See Wiener, supra n. 21, at 200-201 (admonishing advocates not to plan on a canned speech because there will probably be more than one question).

23. Wiener, supra n. 21, at 199-200.

24. See Myron H. Bright, The Power of the Spoken Word: In Defense of Oral Argument, 72 Iowa L. Rev. 35, 36-37 (1986) (quoting Chief Justice Rehnquist as saying that the judge may miss the key point in the brief, and counsel may engage the judge on this point in oral argument).

25. See Hatchett \& Telfer, supra n. 1, at 140 (stating cases that typically go to oral argument are those with such complex issues that the judges require clarification after reading the briefs).

26. See Wiener, supra n. 21, at 200 (stating that a court does not set oral argument unless it believes that the attorneys' participation "would further crystallize the issues....").

27. See Hatchett \& Telfer, supra n. 1, at 140 ("[T] ment typically are the ones that raise 'important' or complex issues or include facts that are so complex that the judges or justices on the appellate panel reviewing the briefs encounter enough difficulty that they require clarification."). 
ify the facts, law, and public policy implications involved with those issues. ${ }^{28}$

Finally, an appellate court's decision in a case inevitably has consequences outside of that case. ${ }^{29}$ For instance, in their decisions, appellate courts often set forth rules of law that will be applied in future cases. ${ }^{30}$ Thus, the court may wish to question the advocates about the impact of its decision on future cases. ${ }^{31}$ For example, if the appellant urges the court to adopt a particular rule of law, the court may ask the advocates questions about how that rule will operate in a case with facts different from the case at bar. ${ }^{32}$

Consequently, as a student advocate, keep in mind the second main purpose behind oral argument is for you to have an educational dialogue with the court about your client's case. Because it is a dialogue, the court will ask you questions that you should answer to the court's satisfaction. Therefore, preparing to answer questions should be a major thrust of your preparation for your oral argument.

\section{B. Brainstorming}

With the purposes of oral argument in mind, you are now ready to begin preparing the argument. The initial stage of preparation should involve a brainstorming session, which you can divide into the following three sub-stages: (1) identifying a theme for your case; (2) identifying the two or three key points that flow from this theme; and (3) anticipating and preparing to answer questions from the court.

\section{Identifying a Theme}

As mentioned above, one of the key purposes behind oral argument is for the advocates to persuade the court that their cli-

28. See Karen J. Williams, Help Us Help You: A Fourth Circuit Primer on Effective Appellate Oral Arguments, 50 S.C. L. Rev. 591, 591, 596 (1999) (suggesting that advocates should be prepared to answer questions on the history, facts, law, and policy of a case).

29. See id. at 596 (discussing the Fourth Circuit's concern about the impact of the decision on future cases).

30. Id.

31. See id. (suggesting that the Fourth Circuit may pose hypotheticals to advocates to test the proposed rule of law's application).

32. Id. 
ent's position is the correct one. To fulfill this purpose, a good oral advocate will identify a succinct theme of the case and convey that theme to the court. ${ }^{33}$ As a student advocate, you too should look for a theme for your case. ${ }^{34}$ This theme should be as simple as possible and should encapsulate your client's case in one or two sentences. ${ }^{35}$ For example, suppose that your client is appealing her criminal conviction, claiming that the prosecutor introduced evidence against her that was unfairly prejudicial to her case because the evidence inflamed the jury's passions. In this situation, your theme could be that a jury's decision against a criminal defendant, to be fair, must be based upon logic rather than emotion, and that the jury in your client's case based its decision upon the latter.

\section{Identifying Your Key Points}

Once you've identified your theme, write it down. You will use it, along with the written arguments made in your brief, to identify the key points you must make to win your case. In doing this, keep in mind that you will have a limited time period within which to present your oral argument. ${ }^{36}$ In most student oral arguments, each advocate is allowed fifteen minutes to present his or her side of the case. Although your brief should cover all of the issues involved in the case, you will probably not be able to present every single point that you made in your brief during your oral argument.

Since you will have a short amount of time to present your side of the case, present only the two or three most important points supporting your argument. ${ }^{37}$ The most important points

33. See Gabriel, supra n. 21, at 573 (listing an important purpose for oral argument as bringing the case together "into a single integrated theme").

34. See Introduction to Advocacy, supra n. 4, at 5-6 (discussing use of the core theory in the argument). For a guide on developing a theme, see Ruggero J. Aldisert, Winning On Appeal: Better Briefs and Oral Argument 192 (2d ed., 2003).

35. Introduction to Advocacy, supra n. 4, at 71; see Gabriel, supra n. 21, at 583-584 (giving the example of a simple and concise theme that the court adopted in its opinion).

36. See e.g. Hatchett \& Telfer, supra n. 1, at 140 ("Today, appellants and appellees are often limited to fifteen minutes or less of oral argument.").

37. Aldisert, supra n. 34, at 359; Jon B. Laramore, Planning and Executing an Effective Appellate Oral Argument 6, in Appellate Oral Argument (1996); see also Myron H. Bright, Focus on the Crucial Issue, 1 J. App. Prac. \& Process 31, 32 (1999) ("[T]he great majority of cases turn on a single issue. At most, perhaps two or three core questions are 
are those you would have to present to the court to win your case if your argument were before a real appellate court. ${ }^{38}$ With your theme in mind, review your brief and highlight these two or three critical arguments. If you do not like to use a highlighter, jot down each critical point on a separate piece of paper. Then, set these points aside, but keep them in mind when you begin to prepare an outline for your argument and when you prepare to answer the court's questions.

\section{Supporting Your Major Points and Preparing to Answer Questions}

Next, you need to consider how you will support the two or three main points in your argument. You also need to ponder the questions that the court may ask you during oral argument and prepare to answer those questions. To do so, try to view the case through the judges' eyes. ${ }^{39}$ Put yourself in the judges' shoes and ask yourself, "If I were a judge in this case, what would I want to know about the case from the advocates?" 40 In nearly every oral argument, the judges will ask questions about the governing legal authorities and the facts appearing in the record of proceedings that support your oral argument. ${ }^{41}$ Therefore, you should be prepared to answer questions about the law and facts. Additionally, judges commonly wish to address the weaknesses of the parties' cases. ${ }^{42}$ Therefore, be especially prepared to answer questions about the weaknesses of your case.

To put yourself in the judges' frame of mind, start by reviewing your brief a second time. Reviewing the brief will direct you to the crucial legal authorities and facts for the case, particularly

crucial.”).

38. See Aldisert, supra n. 34, at 359 (defining an advocate's best point as the point most likely to make the court see the advocate's point of view).

39. See Wiener, supra n. 21 at 200 (suggesting that advocates ask themselves what a judge on the panel would ask); Williams, supra n. 28, at 594, 595 (telling advocates to look at the case through the judge's eyes).

40. Frank M. Coffin, On Appeal: Courts, Lawyering, and Judging 137 (W.W. Norton \& Co., Inc. 1994).

41. See id. at 130 (giving an example argument scenario where the advocate is barraged by questions from the bench about the facts and law).

42. See id. at 132 (describing the goals that judges seek to accomplish in oral arguments). 
those authorities and facts that you must use to support the two or three critical points that you will make to the court.

It should go without saying that you must know well the law applicable to your case. This is because the key function of appellate courts is to determine the outcome of legal issues. ${ }^{43}$ In most cases, appellate courts are required to say what the law is, how it applies to the case before it, and how it should or may apply in future cases. ${ }^{44}$ As a consequence, you can be certain that the court will ask you questions about the law. Therefore, after reviewing your brief a second time, thoroughly review the legal authorities that are crucial to your argument, especially the authorities that directly relate to the key points of your oral argument. For instance, if your argument centers on an issue of federal constitutional law, you should definitely commit to memory the important facts, holding, and reasoning of any United States Supreme Court cases addressing that issue.

You should also reacquaint yourself with the facts of your case. To do this, revisit the record of proceedings from the case. ${ }^{45}$ As you review the record, concentrate on the portions of the record that contain information crucial to your argument. Specifically, look for facts that you need to support the key points of your argument. Then, take a piece of paper and jot down the page numbers of the record that contain information critical to your case. Keep these record citations on hand for use when you put together an outline for your oral argument.

The weaknesses of your case should become apparent to you during your review of your brief, the law, and the record. To further identify the weaknesses of your case, review your opponent's brief to see which issues your opponent emphasizes in support of his or her argument. ${ }^{46}$ Focus on the legal authorities and facts that your opponent cites in his or her brief. Then, conduct a brainstorming session, during which you consider how you can minimize the impact of the weaknesses in your case. ${ }^{47}$ For exam-

43. Williams, supra n. 28 at 596.

44. Id.

45. See Williams, supra n. 28, at 596 (stating that facts and important rulings in previous proceedings should be retrievable "within a second or two").

46. Jason Vail, Oral Argument's Big Challenge: Fielding Questions from the Court, 1 J. App. Prac. \& Process 401, 404 (1999).

47. Id. 
ple, think of how you can factually distinguish unfavorable case law or explain why the court's reasoning in an unfavorable case is inapplicable. Similarly, think of ways to explain why facts unfavorable to your case are not critical to deciding the core legal issues before the court. During this brainstorming session, jot down concise and assertive answers to the court's possible questions regarding the weaknesses of your case. ${ }^{48}$ Keep these answers for reference when you practice your oral argument later in the preparation process.

The standard of appellate review is another area about which the court may question the advocates. ${ }^{49}$ The standard of review is a statement of the level of deference that the appellate court must afford to the lower court decision under review. ${ }^{50}$ In general, appellate courts give great deference to the lower court's determination of the facts and little deference to the lower court's determination of the applicable law. ${ }^{51}$ Because an appellate court needs to be informed on the level of deference it must afford to the lower court's findings, you should anticipate that your judges will ask you about the standard of review. ${ }^{52}$ Know the standard of review and be prepared to discuss it, especially if the standard of review is favorable to you. ${ }^{53}$

More importantly, make sure you understand what the standard of review means. ${ }^{54}$ Frequently, I see student advocates who can state the standard of review during oral argument, but who do not understand what it really means; therefore, they cannot explain the standard's meaning to the judges. This is not uncommon among student advocates because they have little or no litigation experience, and, hence, do not fully understand the process that lower courts use to arrive at decisions. If you do not understand the standard of review, speak to someone who does, such as

\footnotetext{
48. Gabriel, supra n. 21, at 576-577.

49. See Coffin, supra n. 40, at 141 (listing the different possible standards of review).

50. Mary Beth Beazley, A Practical Guide to Appellate Advocacy 12 (2d ed. Aspen Law \& Bus. 2006).

51. Id.

52. Ronald J. Rychlak, Effective Appellate Advocacy: Tips from the Teams, 66 Miss. L.J. 527, 533 (1997).

53. $I d$.

54. See id. (emphasizing that an advocate's understanding of the standard is needed to persuade the court).
} 
a professor or an experienced appellate practitioner, or read a treatise or textbook that discusses the subject. ${ }^{55}$

\section{Preparing an Outline}

The next step in your preparation should be to write an outline for your oral argument. This outline serves two purposes. First, your outline will remind you of the two or three most important points supporting your side of the case. Second, your outline will remind you of critical legal authorities and portions of the record of proceedings about which the court may question you during oral argument.

For student advocates, I recommend the preparation of a short and concise outline rather than an outline that is long and detailed. Many beginning advocates tend to prepare very extensive and detailed outlines because they believe that they will be giving a speech to the court and that they will be unprepared without a detailed outline. In judging moot court arguments, I have even noticed a few students who prepared a verbatim text of the oral argument that they then delivered like a speech.

Remember, however, that an oral argument should be a dialogue between the bench and the advocate, not an uninterrupted speech. ${ }^{56}$ Therefore, you should avoid preparing an extensive outline for your argument. Do not think of your outline as a "crutch" upon which you must lean to deliver your argument. ${ }^{57}$ Instead, prepare an outline that functions as a "safety net," ${ }_{58}$ which is there to catch you if you forget to bring up a critical point needed to support your side of the case, or if you forget to mention a crucial legal authority or fact.

From the standpoint of format, you should begin by writing an outline that contains the two or three key points that support your argument. Place your most important point first. Use bullets or numbers to set each point apart from the others. Use buzz words or key phrases to describe each point rather than long, de-

\footnotetext{
55. I find the discussion of the standard of review in Beazley, supra n. 50, at 12-25, to be very helpful.

56. See Weiner, supra n. 21, at 200, 203 (suggesting a presentation style that is similar to a dialogue).

57. Aldisert, supra n. 34, at 363.

58. Id.
} 
tailed sentences. ${ }^{59}$ By doing this, you will not be tempted to read your argument, and you will seem more natural and conversational as you deliver your argument to the court. Moreover, the more extensively you prepare for and practice your argument, the less likely you will need a detailed outline.

If there is a constitutional provision, statute, or administrative regulation at issue in the case, you might also want to place the relevant portions in your outline. Additionally, include citations to key portions of the record that you compiled while reviewing the record. By placing this important information in your outline, you will be able to immediately access it should the court ask you about it.

Next, gather a set of small note cards. After reviewing the key judicial decisions in support of your argument, use a separate note card to write down the citation for each case. In addition, write a very short synopsis of the case, including the critical facts, holding, and reasoning. While the most important judicial decisions should be fresh in your mind from your thorough review of them, these note cards will permit you to jog your memory during oral argument should you forget certain details about a case.

Then, obtain a manila folder, preferably one that is legalsized, and open it like a book. On the left side of the folder, tape your outline. On the right side of the folder, tape your note cards in a fashion that will allow you to flip through and easily locate the citations and case synopses. Now you should be ready to begin practicing your oral argument.

A final admonition to novices-at several moot court competitions, I have seen a few advocates go up to the podium with no notes or outline at all. While some of the judges commented favorably upon this practice, I do not recommend it. In my opinion, noteless arguments tend to come across as robotic rather than conversational. Furthermore, there's always a chance that an advocate may forget a key point, authority, or fact that could be contained in the advocate's outline. Finally, by and large, this practice does not reflect what goes on in real appellate proceedings.

59. Gabriel, supra n. 21, at 579. 


\section{Practicing Your Argument}

The final stage in preparing to deliver your oral argument is to practice it. Aside from the initial stage of preparing to answer questions by reviewing the briefs, law, and record, practicing your argument is the most important stage of preparation because it enables you to hear criticism and to revise and refine your oral argument. Practicing your argument will also help you to anticipate questions that the judges may ask you during your actual oral argument.

If the rules of your course or competition permit you to do so, practice your argument with the student who has been assigned as your partner (that is, if you have a partner), the students who have been assigned as your opponents, other classmates, law professors, or actual appellate practitioners. Each advocate should take turns delivering his or her oral argument. The advocates who are not arguing (along with any professors or practitioners who are present if they are permitted to judge practice arguments) should serve as judges and ask questions of the student who is presenting the argument.

Vary the time limit for your practice arguments. ${ }^{60}$ During the first practice argument, do not set a time limit so the practice judges can ask as many questions as possible. The more questions the judges ask during practice, the more likely you will be prepared to field a wide array of questions during your actual argument. Depending upon the number of practice arguments you have scheduled, you might not want to have a time limit on the second practice argument. From thereon out, practice your argument using the time limit required by your course or competition's rules.

Additionally, you may practice your argument in front of a mirror. If you do this, take the answers that you thought of during your brainstorming session and rehearse them. You might also present your argument to a parent, friend, spouse, or significant other. Permit this person to serve as a judge and ask you questions. He or she may certainly be someone who does not have any knowledge of the case or the law. You may be surprised at the

60. See Williams, supra n. 28, at 597 (giving an example of how one firm structures its moot court practice sessions). 
insightful questions that come from practice judges who have little to no experience with the law. Similarly, judges who are unfamiliar with the facts and law governing the case will help you prepare for more basic questions and permit you to simplify your presentation because you will have to learn how to explain the facts and the law simply and concisely.

You may find videotaping your practices to be helpful. After practice, review the video. Note questions that you did not anticipate in advance of your practice, and earmark those questions so you can put more time into preparing to answer them in future practices. In addition, watch for any mannerisms that might distract the judges, such as speaking too quickly. ${ }^{61}$ Note these mannerisms for your next practice so you can work on eliminating them.

After practicing, you should revise and refine your argument. For example, you may find that your practice judges focused their questioning on an issue that you did not anticipate in your preparation. If that is the case, you should be prepared to discuss that issue the next time you practice your argument.

One final note about practicing-do not over-practice. While you should be well-versed in the facts, law, and public policy of your case, you can become so saturated with the case that you lose your zeal for it. ${ }^{62}$ It is important that you show enthusiasm for your case to the court during your oral argument. If you lose your eagerness to discuss the case with the court, the tone of your argument will be less persuasive.

\section{E. Other Considerations during Preparation}

There are a few other considerations to be mindful of when preparing for oral argument that do not neatly fit into the steps that I have described. To begin, make sure that you are familiar with the rules or guidelines for the assignment or competition of which your oral argument is a part. Read those rules before you prepare for your argument, read them during your preparation, and read them again shortly before you actually give your oral

61. For a more detailed discussion of stylistic concerns during oral argument, see infra notes 72 to 95 and the accompanying text.

62. Coffin, supra n. 40 , at 140. 
argument. Do not risk losing points on your argument because you violated the rules.

Scout your argument location before your argument, including the building and courtroom where you will argue, if that is possible. ${ }^{63}$ If you know where the courtroom is, you will not risk being late for your argument. Also, you will be familiar with the layout of the courtroom, such as the location of the podium, the bench, and the tables for the advocates.

If you have never seen a real appellate oral argument, watch one. Ideally, go to see one in person at a state or federal appellate court. Many of these courts have an online calendar that lists the dates and times of the oral arguments that the court will hear. ${ }^{64}$ If you cannot see an oral argument in person, some appellate courts have websites with archived digital videos of past oral arguments that you can watch at your leisure. ${ }^{65}$ Regardless of whether you see a live argument or an argument video, I recommend that you view the argument with someone who can accurately critique the advocates' performances, such as your legal writing professor or an experienced appellate lawyer. This person can hold a post-argument review with you to answer your questions and to explain what the advocates did effectively and what they did ineffectively.

Put yourself in a confident frame of mind about your case. Oral advocates who project confidence at the podium are more impressive to the judges than advocates who are meek. The best way to instill self-confidence is to prepare thoroughly during each step of the process that I have described. Good preparation fosters confidence. ${ }^{66}$

63. See Aldisert, supra n. 34, at 330 (suggesting that for "important arguments in unfamiliar locations," attorneys should arrive at least a day and a half early).

64. For example, the U.S. Supreme Court lists its online calendar at http://www .supremecourtus.gov/oral_arguments/oral_arguments.html (last updated Nov. 4, 2008); the Indiana Supreme Court lists its online calendar at http://www.in.gov/judiciary/supreme/ calendar.html (last updated May 22, 2008).

65. For example, the Indiana courts have archived video of appellate arguments at http://www.indianacourts.org/apps/webcasts/default.aspx; the Minnesota Judicial Branch has videos of appellate arguments at http://www.tpt.org/courts; and, the Florida Supreme Court posts is oral arguments for viewing at http://www.wfsu.org/gavel2gavel/index.php.

66. Coffin, supra n. 40, at 143. 
Keep in mind the "big picture" of the case. ${ }^{67}$ Although the court before which you will argue is not a real appellate court, it will function like one and ask questions like one. Appellate courts are always interested in the consequences of their decisions beyond the case at bar. ${ }^{68}$ In other words, they are always thinking of the "big picture" implications of the case. Therefore, you should think of those implications, too. For instance, a lawyer may urge the court on appeal to interpret a statute in a particular way. In deciding whether to adopt this interpretation, the court will undoubtedly consider how the interpretation may impact the operation of the statute in different cases. ${ }^{69}$ Because of this concern, the court will probably test the lawyer's arguments with questions containing hypothetical facts different from the facts in the case at bar. ${ }^{70}$ The lawyer should be aware that these sorts of questions might be asked during the oral argument.

Finally, know the remedy that you are seeking. ${ }^{71}$ Do you want the court to affirm? To reverse? To remand for further proceedings? I am always surprised to see student advocates who are able to deliver a great oral argument on the facts and the law, but are unable to tell the court what result they desire. Again, even though you are not appearing before a real appellate court, treat your moot court as a real court. A real appellate court will certainly want to know the remedy that you seek.

\section{DELIVERING THE ORAL ARGUMENT}

You have prepared for your oral argument, you have practiced it several times, and now you have reached the day on which you will actually deliver your oral argument. If you are competing in a moot court competition, you will probably have to deliver your argument several times, and you will probably have to argue both sides of the case. So how do you proceed?

67. See Williams, supra n. 28, at 596 (noting that aside from knowing the details of a case, it is equally important to understand the "bigger picture" of the case).

68. See id. (indicating that judges not only consider the case at bar, but also how the rule will affect similar cases that follow).

69. Cf. Williams, supra n. 28, at 596 (indicating that judges are concerned with how a new or different rule will impact different cases).

70. See id. (stating that judges ask hypothetical questions to test the rule that an advocate is asking the court to adopt).

71. Gabriel, supra n. 21, at 579. 


\section{A. Getting Started}

When you enter the courtroom for your argument, you should seat yourself at the appropriate counsel table. In the appellate courts of my home state, ${ }^{72}$ counsel for the appellant/petitioner sits at the table on the left side as the parties face the bench, and the appellee/respondent sits at the table on the right side. ${ }^{73}$ Despite this placement of the parties, I have seen courtrooms in other jurisdictions in which the parties are seated in the opposite manner-the appellant/petitioner on the right and the appellee/respondent on the left. ${ }^{74}$ If you have any doubt regarding where to sit, make sure that you find out which table is yours before your argument.

After the bailiff has called the court to order and the judges have taken their places on the bench, the appellant/petitioner will proceed first. ${ }^{75}$ If you are the appellant/petitioner, you should wait to approach the podium until the chief judge of the panel tells you that you may proceed. When you reach the podium, you should not begin speaking until you have the attention of all the judges on the panel. In other words, you know that you may begin when all of the judges are looking at you or the chief judge of the panel tells you to proceed.

As you begin speaking, treat your oral argument as a dialogue with the bench rather than an uninterrupted speech or monologue. ${ }^{76}$ Refrain from reading your argument to the court and maintain as much eye contact with the judges as possible. ${ }^{77}$

72. Professor Dimitri is from Indiana.

73. Instructions for Counsel Scheduled to Present Oral Argument to the Indiana Supreme Court, http://www.in.gov/judiciary/arguments/index.html (accessed Jan. 13, 2009).

74. See United States Court of Appeals for the Fourth Circuit, Oral Argument Procedures, http://www.ca4.uscourts.gov/pdf/oaproc.pdf (accessed Jan. 13, 2009) (allowing advocates to sit at either counsel table).

75. However it is possible for the appellee/respondent to argue first. See U.S. R. S. Ct. 28.2 (Oct. 1, 2007) (stating that normally, the petitioner or appellant shall proceed first, but that in some cases, "the Court will advise the parties who shall open and close"); The Massachusetts Judicial Branch, Clerk's Guide for Counsel and Pro Se Litigants, http://www.mass.gov/courts/sjc/cler-council-and-pro-se-litigants.html (accessed Jan. 13, 2009) (stating that the court's usual practice is to have the appellant argue first; but that the court may alter this sequence).

76. See William H. Rehnquist, The Supreme Court 245-246 (Alfred A. Knopf 2001) (criticizing the "lector" species of oral advocate, who reads his or her argument to the court and treats questions from the bench as unwelcome interruptions).

77. Id. at 246 . 
Indeed, the most important time to maintain eye contact with the judges is at the beginning of your oral argument. ${ }^{78}$ Therefore, you may want to memorize the opening to your argument. ${ }^{79}$

In your opening, it is customary to begin by greeting the judges ("Good morning" or "Good afternoon" will suffice) and stating, "May it please the court." 80 You should also introduce yourself, tell the court which party you represent, and inform the court how much time you have reserved for rebuttal. ${ }^{81}$ After introducing yourself, you should give the court what is typically called a "roadmap." ${ }^{2}$ Your roadmap should begin with the theme that you identified during your preparation. Following the theme, your roadmap should contain your explanation of which issue or issues the case involves and which specific points you will discuss in your argument. ${ }^{83}$ Just as you did in your brief, you should frame your statement of each point persuasively and assertively, in terms that favor your client. ${ }^{84}$ Finally, you should tell the court the remedy you seek. ${ }^{85}$ State the remedy as specifically as possible, whether that remedy is the court's decision of the question presented or a remand to the trial court. 86

In a national moot court competition in which I served as a coach, one of the issues was whether a criminal defense attorney who slept through parts of his client's trial should be presumed to have prejudiced his client in violation of the Sixth Amendment's right to the assistance of counsel. The advocate for the United

78. Never start the argument by reading because as is made abundantly clear by the Rules of the Supreme Court "[o]ral argument read from a prepared text is not favored." U.S. R. S. Ct. 28.1.

79. Aldisert, supra n. 34 , at 358.

80. See Introduction to Advocacy, supra n. 4, at 75, (advising students when beginning the oral argument, they should rise and say, "May it please the court").

81. See Gabriel, supra n. 21, at 582 (suggesting that advocates introduce themselves and state which party they represent); Introduction to Advocacy, supra n. 4, at 79 (suggesting that students reserve time for rebuttal at the beginning of the argument).

82. See Beazley, supra n. 50, at 222 (referring to the section after the opening as a "roadmap").

83. Williams, supra n. 28, at 598. As Judge Williams notes, the introduction is one of the most critical stages of the argument. Id. You may only get a minute or two before questions begin, so you should highlight the critical issues in the case. Id.

84. Rychlak, supra n. 52, at 532. As is the case in any sound appellate brief, persuasive phrasing in the oral argument provides a strong start to your argument. $I d$.

85. Gabriel, supra n. 21, at 579 .

86. Id. 
States, who lost the case in the lower court and appealed that ruling, could have begun his presentation as follows:

Good afternoon, and may it please the court. My name is Jim Dimitri, and I represent the Appellant, the United States of America. With the court's permission, I have reserved two minutes for rebuttal.

Your Honors, the Sixth Amendment to the Constitution does not guarantee a criminal defendant perfect representation by his or her lawyer. It guarantees only competent representation, and that is what the Defendant received in this case.

The issue before this court today is whether a criminal defendant must prove prejudice under the Sixth Amendment when his counsel sleeps during brief portions of the defendant's trial. The United States respectfully asks this court to reverse the judgment of the district court, which presumed prejudice, for three reasons. First, the Sixth Amendment is not violated when defense counsel sleeps through portions of the defendant's trial that are not critical to the defendant's interests, as was the case here. Second, prejudice is normally presumed only when the government is responsible for causing the prejudice. In this case, the prosecutor did nothing to prejudice the defendant. Finally, a presumption of prejudice in cases where counsel sleeps might encourage unscrupulous attorneys to feign sleep in order to secure a reversal of a conviction on appeal.

Following your introduction, if you are the appellant, you may provide the court with a brief recitation of the relevant facts in the case. ${ }^{87}$ In real appellate arguments, many appellants dispense with a recitation of the facts. ${ }^{88}$ An appellant may do this because the time allotted to the parties for argument is normally quite brief and because most judges have already read the briefs and are familiar with the facts. ${ }^{89}$ Whether you, as a student advocate, give a statement of the facts is up to you. At the very least,

87. Rychlak, supra n. 52, at 530-531.

88. See Beazley, supra n. 50, at 222 (noting that most advocates can provide the basic factual context through their articulation of the issue).

89. See id. (explaining the fair presumption that the court has actually read the record and brief prior to oral argument). 
you should ask the judges whether they would like to hear a recitation of the facts. This will give the judges the opportunity to decline if they are already adequately familiar with the facts.

If you do explain the facts, do so very briefly. ${ }^{90}$ Generally, if you take up more than ninety seconds discussing facts, you use time better devoted to discussing the issues. ${ }^{91}$ Therefore, when reciting the facts, focus only on those facts that are relevant to the points you will make in your argument.

After reciting the relevant facts for the court, you should begin with the most important point in your argument, provided that you have not already received questions from the bench. ${ }^{92}$ Your most important point is the point that gives you the best chance of success on appeal. ${ }^{93}$ Argue the most important point first so you do not get sidetracked from conveying your message to the court.

Follow your most important point by discussing the one or two other points that you need to make during your argument. Many novices believe that you should support each point in your argument with many references to citations and legal precedent. I recommend that you avoid this approach because dwelling on citations and precedent will probably bore the court and cause your argument to become unfocused. Moreover, I have heard a few judges remark that an advocate appears evasive when he or she dwells on reciting case law to answer questions from the bench.

Therefore, limit your references to citations and legal precedent. ${ }^{94}$ Support your argument by explaining why your argument presents the most logical approach to solving the issues before the court. Do this in terms of the facts, governing legal concepts, and public policy involved in the case. Weave some equitable concepts into your argument by explaining why you should win in terms of common sense and fairness. ${ }^{95}$

90. Rychlak, supra n. 52, at 532 .

91. This recommended ninety-second time limit is only a guideline, not a hard and fast rule. If the advocate is dealing with a very complex case, the advocate may need to spend more time than ninety seconds explaining the relevant facts.

92. Aldisert, supra n. 34, at 359.

93. Id.; see also Alan L. Dworsky, The Little Book on Oral Argument 59-60 (Fred B. Rothman \& Co. 1991) (advising advocates to "[p]ick your best shot and start with it").

94. Aldisert, supra n. 34, at 361. (stating the detailed discussion of legal precedent should be handled in the brief).

95. Gabriel, supra n. 21, at 584 . 


\section{B. Answering Questions from the Bench}

Rarely is an oral argument uninterrupted by questions from the bench. ${ }^{96}$ Remember, one of the primary reasons courts set cases for oral argument is to ask questions about the case. ${ }^{97}$ Moreover, answering questions is the most important task you will have to handle in an oral argument. In real appeals, whether an advocate wins or loses a case may depend on how effectively the advocate answers the judges' questions during oral argument. ${ }^{98}$ Hence, you should not treat questions from the bench as an intrusion upon your argument. ${ }^{99}$ Rather, you should welcome questions from the bench and strive to answer them to the court's satisfaction. 100

Learning how to properly answer questions from the bench takes time and practice. Jon Laramore, a former colleague of mine who has argued scores of cases before state and federal appellate courts, suggests five steps for answering questions that I find helpful. ${ }^{101}$ Those steps are as follows:

(1) Listen to and understand the question.

(2) Pause to digest the question and think about an answer.

(3) Answer directly.

(4) Explain the answer.

(5) Relate the answer to your argument. ${ }^{102}$

96. See supra n. 21 and accompanying text (explaining that "cold" benches are not commonplace).

97. See supra $\mathrm{nn} .21-23$ and accompanying text (explaining that the educative role of oral arguments is manifested when the court asks questions and the advocate answers them effectively).

98. Vail, supra n. 46, at 402; see also Michael Vitiello, Teaching Effective Oral Argument Skills: Forget about the Drama Coach, 75 Miss. L.J. 869, 888 (2006) (explaining that "a nice [oral argument] style is only peripheral," because "[w]hat matters is the attorney's ability to answer the court's questions thoroughly").

99. Ginsburg, supra n. 5, at 569.

100. Vail, supra n. 46, at 402.

101. John Laramore, Planning and Executing an Effective Appellate Oral Argument, 15 (1996).

102. Id 
First, you should listen carefully to the question. ${ }^{103}$ This means that you must stop talking immediately when a judge asks a question. If you talk over the judges, you may miss part of the question and you may appear to be giving too little deference to the judges. Make sure that you listen to the entire question, not just part of it. If you do not listen to the entire question, you may supply the judge with an answer to only part of the question, not all of it. More importantly, make sure that you understand the judge's question. ${ }^{104}$ If you do not understand the question, politely ask the judge to repeat it. ${ }^{105}$ For example, you may say, "I'm sorry your honor, but I didn't understand your question. Could you please repeat it?"

Second, after listening to and understanding the question, take a brief moment to digest the question in your mind and to think about an answer. ${ }^{106}$ Pausing is important because it gives you the opportunity to really ponder the question and to formulate a complete answer. Do not be frightened by a brief moment of silence in your presentation. Your oral argument does not have to be continuously filled with your speaking. Most judges will expect the advocates to pause momentarily. Some judges may even be flattered that you are displaying some thoughtfulness about their questions by pausing before you answer them.

The third and most important step is to provide a direct answer to the question. ${ }^{107}$ Therefore, never evade a question from the bench, and never put off your answer by saying something like, "I'm going to talk about that in a few minutes."108 If you can answer the question with a "yes" or a "no," do so. ${ }^{109}$ If you do not know the answer to the question, do not try to bluff the judges or evade the question by failing to answer it. Rather, be honest with the court and tell the judges that you do not know the answer to the question and then move on. ${ }^{110}$ If the question is not about a

103. Williams, supra n. 28 , at 599.

104. Id.

105. Rychlak, supra n. 52, at 541.

106. Vail, supra n. 46, at 405.

107. Id.

108. Aldisert, supra n. 34, at 368; Donald M. Peters, Basics of Oral Argument, 32 Ariz. Atty. 18, 28 (1995).

109. Williams, supra n. 28, at 599.

110. Id. at 600 . 
critical area of your case, the judges will appreciate your candor. Of course, there will be critical areas of your case about which you should know, such as the record of proceedings and controlling law. If you are questioned about facts from the record or the controlling law and do not know the answer, refer to your outline. If you cannot find an answer in your outline, tell the court that you do not know the answer, apologize to the court, and move on.

After you have given a direct answer to the question, the fourth step is to explain your answer to the court. ${ }^{111}$ If you have given a "yes" or "no" answer to the court, tell the court the reason for that answer. For instance, if you had to concede a negative point in your case through your answer to a question, explain why that concession should not prevent the court from deciding the case in your favor. ${ }^{112}$

The fifth and final step to answering questions is the most difficult task and requires a lot of practice. ${ }^{113}$ You must find a way to relate your answer to one of the points that you intend to make in your argument, particularly to a point that you have not yet addressed. ${ }^{114}$ In other words, try to use your answer to segue to a related point in your argument if you are ready to begin discussing that particular point. For instance, suppose that to win an appeal, you must show the appellate court that the jury correctly found sufficient evidence to support two elements of a cause of action. ${ }^{115}$ Furthermore, suppose that some of the same facts are used to prove both elements. During the argument, one of the judges asks you to discuss why the facts found by the jury sufficiently support the first element. How might you effectively relate your answer to this question to another point in your argument? You might end your answer to the question with the "overlapping"

111. Id. at 599 .

112. Id.

113. See Aldisert, supra n. 34, at 372 (discussing how to diplomatically disengage from a "barrage of questions for a single judge").

114. Id.

115. Keep in mind that, because appellate courts usually give great deference to a lower court's factual determinations, appeals challenging the sufficiency of a jury verdict are rarely successful. See e.g. U.S. v. Dent, 149 F.3d 180, 187 (3d Cir. 1998) (emphasizing that an appellate court will uphold a jury verdict in a criminal case if "any rational trier of fact could have found the essential elements of the crime beyond a reasonable doubt"). I am using the appeal of a jury verdict as a way of illustrating how to use an answer in an oral argument to segue to the next point in the argument, not to demonstrate that such appeals are advisable or commonplace. 
facts that would help you, to also prove the second element. Then, you might argue that the jury correctly found that the second element was met, initially supporting this argument by relying on the overlapping facts that you just discussed when you answered the court's question about the first element.

As I noted before, many of the questions coming from the bench will focus on the weaknesses of your case. ${ }^{116}$ Sometimes, a judge may ask you to concede or admit to a point, particularly a weakness in your case. ${ }^{117}$ If a judge asks you to concede to a weakness in your case, it may be appropriate to make the concession, particularly if admitting to the weakness will not affect the ultimate outcome of the case or the strength of your argument. Making a concession in this instance permits you to gain credibility because of your candor with the court, which strengthens your argument in the long run. ${ }^{118}$ In addition, advocates who refuse to concede any points may come across to the judges as unreasonable and overly strident. Nonetheless, you should not be too conciliatory with the court, especially if a judge insists that you concede to a point that will result in defeat. If that happens, politely stand your ground and explain why the facts, law, and policy support your position.

Do not assume that all questions from the bench will be about the weaknesses in your case. In real appellate arguments, a judge who agrees with one advocate's position in the case will often ask favorable questions of that advocate.119 Usually, judges ask friendly questions to convince their colleagues on the bench that the advocate being questioned has a valid position and should probably win the case. ${ }^{120}$ You should expect to be asked some friendly questions during your argument. Thus, listen carefully to the questions to recognize friendly questions so you can provide direct and emphatic answers to them.

You should also expect to encounter hypothetical questions from the bench. ${ }^{121}$ Judges ask hypothetical questions to test the

116. Coffin, supra n. 40.

117. Williams, supra n. 28 , at 599

118. Patricia M. Wald, Tips from 19 Years on the Appellate Bench, 1 J. App. Prac. \& Process 7, 19 (1999).

119. Vail, supra n. 46, at 403.

120. Id.

121. Aldisert, supra n. 34, at 371. 
bounds of the positions put forth by the advocates because the court's decisions will affect similar cases in the future. ${ }^{122}$ Of course, a court in a moot court argument will not make an actual decision in the case. Nonetheless, it is not out of the ordinary for moot court judges to ask hypothetical questions. Whatever you do, do not brush off a hypothetical question by responding, "That's not the case before the court." 123 Instead, try to answer the question directly. If you are not sure of the answer to a hypothetical question, there is nothing wrong with admitting that you do not know the answer.

On rare occasions, you may encounter a moot court judge who is quite hostile with his or her questioning. For instance, there may be a judge who persists in pressing you to concede to what he or she perceives to be a weakness in your case. Or, you may have a judge who simply tells you that your argument is stupid. Unfortunately, not all judges are civil with their questioning. No matter how hostile statements or questions from the bench may become, you should be graceful and poised. Tell the judge posing a hostile question or comment that you respectfully disagree and move on with your argument. ${ }^{124}$

If you are participating in a moot court competition, you might be a member of a team in which your partner is arguing another issue to be addressed in the case. When you prepare for your oral argument, you should at least be generally familiar with your partner's issue and argument. You should do this because a judge may ask you a question regarding the issue that your partner is arguing. I would caution against answering such a question by merely saying, "My co-counsel will address that point." Instead, try to answer the question to the best of your ability. Respond briefly to the question, then say, "Co-counsel will develop this discussion further, with the court's permission, since she has prepared to address the answer to the court's question."

Sometimes you may encounter questions from the bench that are tangential or irrelevant to the issues before the court. ${ }^{125} \mathrm{Re}$ -

122. Michael A. Wolff, From the Mouth of a Fish: An Appellate Judge Reflects on Oral Argument, 45 St. Louis U. L.J. 1097, 1102 (2001).

123. Aldisert, supra n. 34 , at 371 .

124. Id. at 372 .

125. Id. 
sist the temptation to characterize the question as irrelevant or unimportant. Do not act as if the judge is creating an inconvenience to you with the question. Rather, be patient with the court and try to answer all questions from the bench, even if they take you off on what you consider to be a tangent. ${ }^{126}$ To avoid being sidetracked, keep your answer to such a question concise and direct. Then, move on to whatever relevant points you need to discuss with the court.

\section{Wrapping Up Your Argument}

After you make the points you need to make and answer all of the court's questions, you should conclude your argument. In real appellate oral arguments, the parties are not required to use up the entire time allotted for the argument. ${ }^{127}$ Therefore, most good appellate lawyers will "quit while they are ahead" and conclude their argument before their time is up if they have made all the necessary points during the argument and have answered all the court's questions. ${ }^{128}$ Some moot court competitions, however, require the advocates to use a minimum number of minutes to make their presentations. ${ }^{129}$ If you are arguing in a moot court competition, make sure that you check the rules of the competition to determine if there are a minimum number of minutes that you must argue. Otherwise, you may conclude before your time has expired, provided you have sufficiently answered all the court's questions and made all the points you must make.

Your conclusion should be brief. I suggest that you concisely revisit your theme, briefly summarize the points that you made during your argument, and repeat the remedy you are seeking from the court. ${ }^{130}$ Unless you were able to conclude earlier, you should give your conclusion with at least thirty seconds to a minute to spare in your argument, if this is possible. However, you may be in the middle of answering a question from the court when your time expires. If this occurs, acknowledge that your

126. Vail, supra n. 46 , at 403

127. E.g. U.S. S. Ct. 28.3 (“Counsel is not required to use all the allotted time.").

128. Aldisert, supra n. 34 at 362 .

129. The American Constitution Society for Law and Policy, 2008 Constance Baker Motley National Moot Court Competition Rules, http://www.acslaw.org/mootcourtrules (accessed Jan. 13, 2009) (allocating a minimum of ten minutes per advocate).

130. Rychlak, supra n. 52, at 545. 
time is up and ask the court for permission to continue your answer. I have never seen a court refuse this request. Then, after you have finished your answer, say, "Thank you," and sit down. Do not launch into a prepared conclusion in which you reiterate the points you have made and repeat your prayer for relief.

\section{Rebuttal}

After the appellee has presented his or her argument, the appellant has an opportunity to give a short rebuttal. ${ }^{131}$ If you are giving a rebuttal, reserve no more than two or three minutes to do so. If you reserve more time than this, ${ }^{132}$ you will probably take away time that you will need to address the issues during your opening argument. You should reserve time for rebuttal, regardless of whether you actually use that time. ${ }^{133}$ If you do not reserve rebuttal time, you will be unable to correct any factual or legal misstatements that opposing counsel made during his or her argument.

To "rebut" something means to refute it or to respond to it. ${ }^{134}$ If you represent the appellant, you should keep this meaning in mind because you should use your rebuttal only to respond to points that the appellee raised in his or her argument. For example, you might use your rebuttal to correct or clarify any misstatements or unclear characterizations of the facts or the law that your opposing counsel made in his or her argument. Never use rebuttal to raise new issues or to raise points that you were unable to cover in your opening argument. ${ }^{135}$ This is not the pur-

131. Id. at 544 (explaining that the appellant is given rebuttal time for two reasons: first, the appellant has the burden of proof; and second, it allows each side to comment on its opponent's arguments).

132. In typical moot court competitions, the appellant/petitioner is permitted to reserve up to five minutes for rebuttal. International Trademark Association, 2008-2009 Saul Lefkowitz Moot Court Competition Official Rules, http://www.inta.org/images/stories/ Academics/Documents/2008-2009_lefkowitzofficialrules.pdf; (accessed Jan. 13, 2009) (allowing five minutes for rebuttal).

133. Aldisert, supra n. 34, at 378. Of course, you are not required to use the rebuttal time you have reserved. Indeed, declining to give a rebuttal may indicate to the court that your case is still strong even after the appellee has presented his or her argument. Introduction to Advocacy, supra n. 4, at 79. Nonetheless, I find it a rare occasion on which counsel for the appellant is left with nothing to respond to after the appellee's argument.

134. Random House Webster's Unabridged Dictionary 1609 (2d ed., Random House 2001).

135. Aldisert, supra n. 34, at 378. 
pose of rebuttal, and the judges will not be pleased if you use rebuttal to cover points you neglected in your opening argument. ${ }^{136}$

Because the time allotted for rebuttal will be brief, you should cover no more than one or two points in your rebuttal. Be concise and direct in discussing these points. In addition, listen carefully and closely to your opposing counsel's argument. Otherwise, you will not have anything to talk about on rebuttal. For example, you may fail to address an unclear characterization of the law made by opposing counsel.

If you are counsel for the appellee, you may believe that you are at a disadvantage because the appellant has the last word with rebuttal. This, however, is a mistaken belief. Indeed, the appellee's argument is, in part, a rebuttal of the appellant's opening argument. A good advocate arguing on the appellee's behalf will not be a slave to her outline. Rather, the good advocate will be flexible; she will listen closely to the appellant's opening argument and will take note of any incorrect or unclear characterizations of the facts or the law. She will then incorporate into her argument a rebuttal to those mischaracterizations. In sum, if you represent the appellee, you should "go with the flow" and modify your argument according to what the appellant says during her opening argument.

E. Appearance, Mechanics, and Miscellaneous Advice

Your physical appearance for an oral argument should be business-like and conservative. ${ }^{137}$ Both male and female advocates should dress in a dark, conservative business suit. ${ }^{138}$ Avoid flamboyant or provocative ties, shirts, blouses, and shoes. Advocates should button their suit jacket before approaching the podium.

It is possible, though unlikely, that a judge may consider a pantsuit worn by a female advocate as too informal. Still, female advocates should feel free to wear pantsuits. If you err on the side

136. See e.g. Beazley, supra n. 50, at 230 ("many courts will interrupt counsel who try to use rebuttal to 'finish up' the main argument, saying, 'counselor do you have any rebuttal to offer?"').

137. Aldisert, supra n. 34, at 355 (quoting from King Lear, "Through tattered clothes small vices do appear").

138. Id. 
of caution and wear a skirt, make sure that it is of a conservative length. Do not show up for an argument wearing a mini-skirt. In other words, do not emulate the unrealistically hip business attire that you may see on television shows like Boston Legal. ${ }^{139}$

Your posture at the podium should be even. Stand up straight and face the bench. Do not stand leaning on one leg, and do not shift your weight from one leg to the other. Rather, remain stationary. If you have a tendency to get lightheaded, you should not lock your knees; instead, bend them slightly.

Eye contact with the judges is extremely important during your presentation. ${ }^{140}$ Remember, you want to maintain a conversational tone with the judges, and eye contact with the bench will aid you in that goal. Further, when a judge asks you a question, you should make eye contact with the whole bench, not just the judge who asked you the question. ${ }^{141}$

Your delivery of your argument should be clear and deliberate. Use simple, concise sentences to promote comprehension. Do not speak too quickly or rush through your argument because you will be hard to understand. Furthermore, avoid a monotonous or meek delivery. The late Chief Justice William Rehnquist of the United States Supreme Court suggested that advocates have a "controlled enthusiasm" for their case. ${ }^{142}$ This means that you should use some vocal inflection for emphasis to show the court that you believe in your case. ${ }^{143}$ It also means that you should avoid being overly dramatic with your argument. ${ }^{144}$ For example, do not pound on the podium or raise your voice too loudly. You may gesture with your hands, but do not overdo it to the point that it becomes distracting. I have a tendency to gesture a lot when I speak. To prevent distraction during oral argument, I typically fold my hands in front of me.

139. ABC Inc., Boston Legal, Photo Gallery, http://abc.go.com/primetime/bostonlegal/ index?pn=photos\#t=41238 (accessed Jan. 13, 2009).

140. Rychlak, supra n. 52, at 536.

141. Id.

142. Rehnquist, supra n. 76 , at 248.

143. See Lawrence D. Rosenberg, Using the Lessons of Aristotle to Present Outstanding Oral Arguments, ABA J. Sec. of Litig. 1 (Summer 2006), available at http://www.abanet .org/litigation/committees/trialpractice/articles.html (defining "ethos" as "the speaker's power of evincing a personal character that will make his speech credible").

144. See id. at 13-14 (joking that this type of behavior removes one from the desirable realm of "ethos, pathos, and logos" to the realm of "lame'os"). 
Avoid verbal pauses and verbal filler. Verbal pauses are the "uhs" and "ums" that some people use when speaking. Speakers often use verbal pauses when they are thinking of what to say. Instead of using verbal pauses, simply pause silently. Verbal filler is language that a speaker unnecessarily uses to preface a point that he or she is making. For example, an advocate may say, "It is the Appellant's position that the court should reverse the decision of the trial court," or, "We would submit that the case mentioned by opposing counsel is not controlling." Verbal filler is unnecessary because it lengthens your argument and weakens the impact of your advocacy. Therefore, eliminate it from your argument completely.

Your demeanor should be deferential but firm. Refer to each judge as "your Honor" or by the judge's title and name, such as "Justice Souter." Refer to the judges collectively as "this court" or "your Honors." As my legal writing professor used to remind me, an oral argument is not a military exercise; therefore, I suggest that you not call the judges "ma'am" or "sir." 145 Further, do not take a defensive tone with the judges. One of the worst things that you can do during an oral argument is to fight with a judge regarding a point about which you disagree. This may make the judge upset at you and will unquestionably cause you to lose the respect of the court. However, it is certainly permissible to disagree with a judge as long as you do so respectfully. If you do not agree with a judge's assessment of an issue or point, say, "Your Honor, I respectfully disagree" and then use the facts and the law to give the reasons why you disagree. ${ }^{146}$ Logic is your best ally in this situation.

If you are making a point in response to a judge's question that you made before in your argument, avoid prefacing your statement with "As I said before," or, "As I said earlier." Some judges may be offended by these prefatory comments because to them they may mean, "Why weren't you listening to me before?" Similarly, avoid prefacing statements with intensifiers such as

145. John P. Erlick, Professionalism in the Courtroom, http://www.wsba.org/media/ publications/barnews/aug08-erlick.htm (accessed Jan. 13, 2009). I understand that in some regions of the United States, it is acceptable to address judges as "ma'am" or "sir." While this may be the case, I recommend that you not use these forms of address for the judge unless you are absolutely sure they are acceptable.

146. Aldisert, supra n. 34 at, 372 . 
"clearly" or "obviously," especially if you are making a key legal point in your argument. For instance, you would not want to say, "Clearly the trial court incorrectly decided this case." If this were "clear," there would be no need for oral argument. Moreover, judges tune out this sort of language because lawyers tend to overuse it.

Avoid reading long quotations from the record or the case law you are using to support your arguments because you will bore the judges if you do. This does not mean that you may never quote from the record or the law. If you do so, keep the quotation short.

Finally, be yourself during oral argument. Everyone has a different style of speaking, so you should not try to mimic the speaking style of other advocates. If you have prepared well for your oral argument, then you can afford to be yourself because you will give a good oral argument.

\section{CONCLUSION}

As a newcomer to appellate oral advocacy, you now have a comprehensive set of instructions that will help you embark on your new journey with a sense of security and confidence. As discussed above, only well-prepared advocates are capable of delivering an effective oral argument that functions as an educational dialogue between attorney and bench. Effective oral advocates understand their dual roles as persuaders and educators, know the facts and the law, anticipate and prepare to answer questions, and practice their argument before setting foot in the courtroom. With this preparation under their belts, good advocates step up to the podium and lay out a clear roadmap for the judges. After this roadmap, they succinctly and clearly set forth the contentions they need to make to win the case and field questions from the bench courteously, providing direct, well-reasoned answers. 